\title{
Emotions, Poverty, or Politics? Misconceptions about Islamist Movements
}

By Anne Marie Baylouny*

In recent years violent movements in the name of Islam have been catapulted to center stage in U.S. foreign policy concerns. However, before concrete strategies can be formulated to deal with this phenomenon, the nature and dynamics of Islamist mobilization itself must be understood ${ }^{-1}$ What motivates an individual to join an Islamist group and possibly engage in violence? Under what conditions will these groups moderate their stances, and when will they radicalize? While our policy choices dealing with the Muslim world and international terrorism inevitably hinge on our answers to these questions, a serious application of theory has been lacking. ${ }^{2}$

Lessons culled from the study of contentious or claim-making politics provide valuable insight into unraveling the complicated political allegiances in the Muslim world and further contribute to the formulation of policy prescriptions to defuse Islamist movements' violent manifestations. Social movement theory in particular demonstrates that local political inclusion can stimulate moderation, stemming the progression of militant Islamism in its infancy.

\section{Theoretical Explanations and Inadequacies}

Analyses of the roots of Islamism have typically been based upon emotions, economic desperation, or cultural anger. By this line of reasoning, poverty, rejection of Western culture, or lack of hope for the future spur involvement in groups that aim, either through the creation of an Islamic state or isolation from the global community, to return the Muslim world to a past state of glory. Some link Islamism with poverty and deprivation. Others, including Islamists themselves, reiterate Samuel Huntington's claim that the West is culturally opposed to the rest of the world. Under these theories, policies to decrease Islamism's appeal would thus center on either economic growth or cultural separation; the rest of the world should work to either increase living standards in Muslim nations or relax their pace of integration into the international economy.

\footnotetext{
* Anne Marie Baylouny is Assistant Professor in the department of National Security Affairs at the Naval Postgraduate School. This paper appeared in an earlier form in Strategic Insights, the monthly electronic journal of the Center for Contemporary Conflict at the Naval Postgraduate School.

${ }^{1}$ The term "Islamism" or "political Islam" is preferable to "Islamic fundamentalism," since the term fundamentalism is derived from the Protestant Christian context and only loosely fits the movement in Islam.

${ }^{2}$ Middle East and Islamic specialists are often area-bound, remaining uninfluenced by social science's extensive research into oppositional politics and unwittingly operating with discredited theoretical frameworks. Theory-oriented scholars for their part generally steer clear of Islamism, perhaps out of a belief in the area's presumed cultural exceptionalism, or due to its admittedly complicated particulars.
} 
Appealing as those objectives may be to many, the data on Islamism, and on oppositional movements in general, indicate that the equation of economic or cultural distress with Islamism is misplaced, or at the very least incomplete.

Islamism, according to these psychologically- and economic-based explanations, is the result of an explosion of pent-up grievances, ${ }^{3}$ the last resort of a person "fed up" and gone crazy. ${ }^{4}$ While it makes intuitive sense, this theory does not fit the reality. Varying economic circumstances across regions and time periods do not match the occurrence of rebellions and protest movements, as many scholars have shown. ${ }^{5}$ In fact, economic grievances abound throughout history, yet movements based on them have been rare. When is a grievance bad enough to start a movement? And why do starving populations often not rebel, while their well-off neighbors do? Iran's Islamist revolution occurred in a context of economic plenty, and an analysis of Muslim countries demonstrates the lack of fit between this theory and the actual history of Islamist actions. ${ }^{6}$

The social background of individual movement members further demonstrates the fallacy of such ideas. Islamist activists are neither economically deprived nor culturally traditional. They are neither loners nor marginal individuals searching for meaning and belonging, persons unable to get along in modern society. Instead, Islamists come from the most technically advanced sectors of society, often students or graduates of engineering and the technical sciences. Islamist activists are well rooted in their communities and have extensive personal networks, parallel to nationalistic terrorists in other regions of the world. ${ }^{7}$ The September 11 terrorists, along with suicide bombers in the Palestinian territories, are a testament to this profile. ${ }^{8}$ A survey of Hizballah adherents found that, despite its rhetoric, the party was not in fact the representative of the lower class; rather, the bulk of its support came from the middle and upper classes. ${ }^{9}$

Focusing on religion or religiosity to identify Islamists is similarly misguided. Religiosity and involvement in political Islam are not directly correlat-

${ }^{3}$ This is the relative deprivation thesis of rebellion, pioneered by Ted Robert Gurr in Why Men Rebel (Princeton, NJ: Princeton University Press, 1970).

${ }^{4}$ A student aptly compared this theory to the Michael Douglas movie, Falling Down.

${ }^{5}$ See Mohammed M. Hafez, Why Muslims Rebel: Repression and Resistance in the Islamic World (Boulder, CO: Lynne Rienner, 2003); Sidney Tarrow, Power in Movement: Social Movements and Contentious Politics, $2^{\text {nd }}$ ed. (New York: Cambridge University Press, 1998); Charles Tilly, Popular Contention in Great Britain, 1758-1834 (Cambridge, MA: Harvard University Press, 1995); and Charles Tilly, From Mobilization to Revolution (New York: McGraw-Hill, 1978).

${ }^{6}$ Hafez, Why Muslims Rebel.

${ }^{7}$ See Peter Waldmann, "Ethnic and Sociorevolutionary Terrorism: A Comparison of Structures," 237-57, and Donatella Della Porta. "Introduction: On Individual Motivations in Underground Political Organizations," 3-28, both in Social Movements and Violence: Participation in Underground Organizations, ed. Donatella Della Porta (Greenwich, CT: JAI Press, 1992).

${ }^{8}$ On the latter, see Lori Allen, "There Are Many Reasons Why: Suicide Bombers and Martyrs in Palestine," Middle East Report 223 (Summer 2002): 34-37.

9 Judith Palmer Harik, "Between Islam and the System: Sources and Implications of Popular Support for Lebanon's Hizballah," Journal of Conflict Resolution 40:1 (March 1996): 55. 
ed; Islamists and their supporters are not more religious than non-Islamists. Similarly, the level of support for Islamist movements diverges sharply from the level of popular acceptance of their goals - particularly the establishment of an Islamic state. In Lebanon, the overwhelming majority of Hizballah adherents, along with most Shi'ites in general, prefer a Western political system (modeled on Switzerland or the United States), not a theocratic one. Discrepancies exist between the percentage of people who voted for Hizballah and those who chose it as their favored political party, with lower ratings for the latter - indicating the practice of strategic voting instead of widespread belief in the movement itself. Hizballah members are not significantly more religious than the adherents of secular political parties. In fact, a significant number of the highly religious declared themselves opposed to the establishment of Islamic political parties. ${ }^{10}$ Surveys in the West Bank and Gaza found similar opinions. Overall, less than three percent of Palestinians in the territories desired an Islamic state, while almost twenty-one percent trusted Hamas more than any other political faction. ${ }^{11}$

In fact, culture and economics are only indirectly related to Islamist mobilization for violent and moderate groups alike. ${ }^{12}$ Grievances alone do not create a movement. At most, they are but one element that organizers can exploit to aid in organizing. Directly contradicting explanations of Islamism based in economic deprivation is the fact that substantial resources and networks are necessary for movements to organize. ${ }^{13}$ Leaders generally come from relatively privileged social groups. Thus, the substance of the movement and its ability to mobilize members are more important than the broad statements about motivations picked up by the Western press. What does it take to attract an initial following and then organize it into a network?

\section{Social Movement Theory and Islamist Responses to Democratic Carrots}

Theories of contentious or adversarial politics, of which social movement theory is the most prominent branch, are well situated to address these issues. ${ }^{14}$

\footnotetext{
${ }^{10} \mathrm{~A}$ significant percentage of the highly religious were found to be most distrustful of religious political parties. Harik, "Between Islam and the System," 41-67. Confirming these findings, see Hamzeh's data cited in Augustus Richard Norton, "Religious Resurgence and Political Mobilization of the Shi'a in Lebanon," in Religious Resurgence and Politics in the Contemporary World, ed. Emile Sahliyeh (Albany: State University of New York Press, 1990), 229-41.

${ }^{11}$ Interestingly, support for an Islamic state in the West Bank was higher than in the Gaza Strip, the home territory of Hamas. Jerusalem Media and Communication Center, Public Opinion Poll No. 42: On Palestinian Attitudes Towards Politics Including the Current Intifada-September 2001, www.jmcc.org/publicpoll/results/2001/no42/htm.

12 The prevailing typology to date distinguishes between radical (that is, violent or extremist) and moderate movements. This categorization can be based either on the tactics the movement chooses or, more commonly, their stated end goals in relation to the current political system. The moderates work within the system, often concentrating on social welfare or civil society organizations.

${ }^{13}$ John D. McCarthy and Mayer N. Zald, "Resource Mobilization and Social Movements: A Partial Theory," American Journal of Sociology 82:6 (May 1977): 1212-41.
} 
Social movement theory has long addressed the questions of terrorism and violent conflict. Through the lens of social movement theory, the conundrum of Islamism, so baffling from other perspectives, becomes clear. Beyond the demonstrations and letter-writing campaigns common to democratic systems, contentious politics span a continuum from riots to revolutions and terrorism. ${ }^{15}$ Non-violent movements more typically recognized as social movements are included, but these are rare in authoritarian systems.

Despite the claims of movement adherents, the real motivating grievances of Islamism are local issues. Like other social movements, including the anti-globalization campaign, the concerns that motivate Islamists center on their towns, their states, and their local economies. Islamist movements differ considerably from each other, having been molded by the states they oppose, the resources available to them, their networks, and other specifically local factors. Even within the same state, movements can have radically opposed motivating agendas. Some even compete and attempt to defeat other Islamist movements. ${ }^{16}$ Statements by group leaders and Islamist charters should thus be viewed in light of their actions in response to concrete changes. Publicly, Hamas may well adhere to its goal of eradicating Israel, yet its practice has in fact been moderated. What conditions will bring about a truce or, alternatively, a willingness to establish a legitimate political party and participate in democratic elections? ${ }^{17}$ As Tilly stated, the "rhetoric of rebellion" does not equate to the actual grievance. Viewing the entirety of movement practices, instead of simply their statements, reveals an alternative logic. ${ }^{18}$

Acknowledging Islamism as a form of oppositional politics indicates that its trajectory is not random, but is instead governed by political considerations and strategic calculations. It can develop into different forms of protest

\footnotetext{
${ }^{14}$ For social movement theory, see Doug McAdam, Sidney Tarrow, and Charles Tilly, Dynamics of Contention (New York: Cambridge University Press, 2001); and by the same authors, "To Map Contentious Politics," Mobilization 1:1 (1996): 17-34.

${ }^{15}$ Following Tarrow, contentious politics can be defined as collective activity on the part of claimants that uses extra-institutional channels to communicate their demands. Demands and the activities to achieve them exist in relation to the prevailing political system, members of the elite, or the opposition. Social movements are oppositional challenges, which are sustained continuously beyond the distinct moment of protest. Sidney Tarrow, "Political Protest and Social Change: Analyzing Politics," American Political Science Review 90:4 (December 1996): 874-83.

${ }^{16}$ Prominent examples are the various movements in Egypt. Mamoun Fandy, "Egypt's Islamic Group: Regional Revenge?" Middle East Journal 48:4 (Autumn 1994): 607-25; Ziad Munson, "Islamic Mobilization: Social Movement Theory and the Egyptian Muslim Brotherhood," Sociological Quarterly 42:4 (2001): 487-510; David Zeidan, "Radical Islam in Egypt: A Comparison of Two Groups," in Revolutionaries and Reformers: Contemporary Islamist Movements in the Middle East, ed. Barry Rubin (Albany: State University of New York Press, 2003), 11-22.

${ }^{17}$ See Shaul Mishal and Avraham Sela, "Participation without Presence: Hamas, the Palestinian Authority and the Politics of Negotiated Coexistence," Middle Eastern Studies 38:3 (July 2002): 1-26; and Robert A. Pape, "The Strategic Logic of Suicide Terrorism," American Political Science Review 97:3 (August 2003): 343-61.

${ }_{18}$ Tilly, Mobilization to Revolution, 234.
} 
and organizing, including civil society and social welfare associations, given appropriate and credible incentives. The relevant influences for these movements are the array of political opportunities they face. The key questions for policy makers are, what are the prevailing power relations, how does the group want these relations to change, and what paths to inclusion in the political system are open or blocked? The third question includes splits among elites that movements can exploit, opportunities to partake in electoral politics, and the character of repression by the state.

Exclusion or inclusion from the political system plays a powerful role in radicalizing movements. While fears of "one person, one vote, one time" will remain, the data indicate that, when given the opportunity to participate in politics at the price of moderation, movements will alter their very nature to respond to this stimulus. Hizballah's experience demonstrates this dynamic. Not only has the group moderated its positions in order to enter electoral politics, but it also reframed its central objective, foregoing its stated goal of an Islamic state. Lebanon's substantial Christian population makes this a special case, to which Hizballah must be sensitive in order to avoid renewed conflict. ${ }^{19}$ The party formed alliances with Christians and supported Christian candidates in elections. The incentives Hizbullah responded to demonstrate the fundamental logic of the movement, notwithstanding any rhetoric to the contrary.

Democratic theory has long held that participation in the formal political arena moderates political parties. Movements are co-opted, choosing to work within the limits of the system. They hope for change through the political process, rather than the risky option of violent conflict. Furthermore, once leaders or political parties have obtained a vested interest in the system, they will exert pressure upon the more radical wings of their movements not to jeopardize their established position. On the other hand, when the opposition party is illegal, no incentive to moderate exists.

To mobilize continuous support, organizations must provide public demonstrations of the movement's endurance, a sort of advertising or communication with the constituency. Newsletters may work for Greenpeace, but an illegal movement must employ alternative public means to advertise its existence. ${ }^{20} \mathrm{CNN}$ is perfect for international movements; local news suffices for domestic movements. Violence is one tactic that can be used to glue the movement together, create an identity, and promote group solidarity. Absent viable participation in the political realm, violence also serves the movement function of communicating demands to authorities. ${ }^{21}$ When groups are legal, public per-

\footnotetext{
${ }^{19}$ See Nizar A. Hamzeh, "Lebanon's Hizbullah: From Islamic Revolution to Parliamentary Accommodation," Third World Quarterly 14:2 (1993): 321-37; Muhammad Hussayn Fadlallah, "Interview: Islamic Unity and Political Change,” Journal of Palestine Studies 25:1 (Autumn 1995): 61-75.

${ }^{20}$ Social movements make collective demands and undertake mobilizing or other public activities that unify the constituency. Charles Tilly, "From Interactions to Outcomes in Social Movements," in How Social Movements Matter, ed. Marco Giugni, Doug McAdam, and Charles Tilly (Minneapolis: University of Minnesota Press, 1999), 253-70.
} 
formances such as demonstrations can perform this vital role. Legalization provides an alternative, legitimate means to secure organizational survival.

In addition, movements do not merely build upon pre-existing identities or reflect group feelings already in place. Instead, social movements actively fashion new identities, mainly through the technique of framing. Framing is the formulation of ideological schemes akin to slogans that sell the movement to a constituency. Frames must resonate with the population by tapping into existing symbols, while at the same time transforming their cultural meanings. Problems are spun as unjust grievances for which clear blame can be assessed and a solution proposed by the movement. Familiar symbols are used in novel ways, much in the way that liberation theology altered Christianity by reframing poverty, once accepted as an act of God, as a social issue of fundamental injustice.

Religion plays a key role in Islamist movements, but not due to doctrinal specifics or the religiosity of Islamists. The practice of Islam within Islamist movements has been shown to be malleable, adopting aspects of nationalism and leftist or Leninist mobilization often deemed antithetical to the religious doctrine itself. ${ }^{22}$ Religious movements have distinct advantages in authoritarian contexts. Islam provides a frame for solidarity, particularly when other organizing is forbidden. Not only can religious movements monopolize the organizing field, due to frequently harsh restrictions on mobilizing, but religion also provides symbols of justice extending beyond the individual's rational cost-benefit calculus. ${ }^{23}$ In non-democratic environments, symbolic protest - the veil, the kaffiyeh, the colors of the flag, or vague slogans such as "Islam is the solution" - dominates political communication. The resources and networks requisite to mobilizing support, integral to social movement success, are also found in religion's institutional legacy and its charitable activities. In most of the Middle East, Islamist movements had been promoted by the state in previous decades as a counter to the left, a harvest whose fruit the region is now reaping. ${ }^{24}$ Currently, Islamist charities substitute for the state's bankrupt social welfare institutions.

The democratic process itself may well be central to removing the

${ }^{21}$ Violence may be unrelated to the movement's actual goals, but can serve instead purely to create organizational cohesion. Martha Crenshaw, "Theories of Terrorism: Instrumental and Organizational Approaches," in Inside Terrorist Organizations, ed. David C. Rapoport (Portland, OR: Frank Cass, 2001), 13-31.

${ }^{22}$ Henry Munson, "Islam, Nationalism and Resentment of Foreign Domination," Middle East Policy 10:2 (Summer 2003): 40-53; As'ad Abu-Khalil. "Ideology and Practice of Hizballah in Lebanon: Islamicization of Leninist Organizational Principles," Middle Eastern Studies 27:3 (July 1991): 390-403.

${ }^{23}$ Ron Aminzade and Elizabeth J. Perry, "The Sacred, Religious, and Secular in Contentious Politics: Blurring Boundaries," in Silence and Voice in the Study of Contentious Politics, ed. Ronald R. Aminzade, Jack A. Goldstone, Doug McAdam, Elizabeth J. Perry, Jr., William H. Sewell, Sidney Tarrow, and Charles Tilly (New York: Cambridge University Press, 2001), 155-78.

${ }^{24}$ Joel Beinin and Joe Stork, "On the Modernity, Historical Specificity, and International Context of Political Islam," in Political Islam: Essays from Middle East Report, ed. Joel Beinin and Joe Stork (Berkeley: University of California Press, 1997), 3-25. 
impetus for violent tactics in Islamist movements; however, this democracy must be considered fair, authentic, and legitimate within the states in question. The Arab world is rife with countries whose elections display a democratic façade, while substantive violations pervade the process, escaping international criticism. Many more countries use the rhetoric of Islamism to deny civil liberties and basic human rights, fueling precisely the dynamic which drives targeted organizations to use violent tactics in their fight with the opposition. Any policy of encouraging democracy must be uniform, neither barring participants from the democratic process nor canceling elections Algerian-style.

\section{Conclusion}

Islamism is one of the most important geopolitical topics today, yet misconceptions about it abound. We lose a great deal by ignoring the knowledge generated through years of study in other parts of the world, data that could aid in correctly identifying what Islamism is, what causes it, when it turns violent, and how best to meet our policy aims regarding it. Movement pragmatism provides an opportunity to craft targeted policies. Disregarding the tendency of Islamist movements to respond to democratic incentives is tantamount to the tunnel vision that led to surprise at the fall of the Soviet Union or the revolution in Iran.

Some individuals and groups may be beyond the pale, immune to the blandishments of democratic politics. But even these hard-line groups originally grew out of local politics, and could have been defused at that level. The "Arab Afghanis," or Arabs who fought in the Afghan war, first earned their stripes in radicalization on the local front. Repressed and unable to operate in their own countries, they emigrated, eventually joining international groups, which lack a local social base. This process can be halted at the local level by identifying the operative political grievances and opening the political realm to contestation. For Islamist leaders to become political players, they must expand their constituency and be accountable to it. Given the disjuncture between the populace's goals and those of Islamist elites, moderation would most likely result. 


\section{Bibliography}

Abu-Khalil, As'ad. "Ideology and Practice of Hizballah in Lebanon: Islamicization of Leninist Organizational Principles." Middle Eastern Studies 27, no. 3 (1991): 390-403.

Allen, Lori. "There Are Many Reasons Why: Suicide Bombers and Martyrs in Palestine." Middle East Report 223 (2002): 34-37 .

Beinin, Joel, and Joe Stork. "On the Modernity, Historical Specificity, and International Context of Political Islam." In Political Islam: Essays from Middle East Report. Berkeley: University of California Press, 1997.

Fadlallah, Muhammad Hussayn. "Interview: Islamic Unity and Political Change." Journal of Palestine Studies 25, no. 1 (1995): 61-75.

Fandy, Mamoun. "Egypt's Islamic Group: Regional Revenge?" Middle East Journal 48, no. 4 (1994): 607-25.

Hafez, M.. Why Muslims Rebel: Repression and Resistance in the Islamic World. Boulder, CO: Lynne Rienner, 2003.

Hamzeh, A.. "Lebanon's Hizbullah: From Islamic Revolution to Parliamentary Accommodation." Third World Quarterly 14, no. 2 (1993): 321-37.

Harik, Judith Palmer. "Between Islam and the System: Sources and Implications of Popular Support for Lebanon's Hizballah." Journal of Conflict Resolution 40, no. 1 (1996).

McAdam, Doug, Sidney Tarrow, and Charles Tilly. "To Map Contentious Politics." Mobilization 1, no. 1 (1996): 17-34.

McAdam, Doug, Sidney Tarrow, and Charles Tilly. Dynamics of Contention. New York: Cambridge University Press, 2001.

Mishal, Shaul, and Avraham Sela. "Participation without Presence: Hamas, the Palestinian Authority and the Politics of Negotiated Coexistence." Middle Eastern Studies 38, no. 3 (2002).

Munson, Henry. "Islam, Nationalism and Resentment of Foreign Domination." Middle East Policy 10, no. 2 (2003): 40-53.

Munson, Ziad. "Islamic Mobilization: Social Movement Theory and the Egyptian Muslim Brotherhood." Sociological Quarterly 42, no. 4 (2001): 487510 .

Norton, Augustus Richard. "Religious Resurgence and Political Mobilization of the Shi'a in Lebanon." In Religious Resurgence and Politics in the Contemporary World, 229-241. Albany: State University of New York Press, 1990.

Pape, Robert A.. "The Strategic Logic of Suicide Terrorism." American Political Science Review 97, no. 3 (2003): 343-61 . 
Porta, Donatella Della. Introduction: On Individual Motivations in Underground Political Organizations. Greenwich, CT: JAI Press, 1992.

Tarrow, Sidney. "Political Protest and Social Change: Analyzing Politics." American Political Science Review 90, no. 4 (1996).

Tarrow, Sidney. Power in Movement: Social Movements and Contentious Politics. New York: Cambridge University Press, 1998.

Tilly, Charles. "From Interactions to Outcomes in Social Movements." In How Social Movements Matter. Minneapolis: University of Minnesota Press, 1999.

Waldmann, Peter. Ethnic and Sociorevolutionary Terrorism: A Comparison of Structures., 1992.

Zald, Mayer N.. "Resource Mobilization and Social Movements: A Partial Theory." American Journal of Sociology 82, no. 6 (1977): 1212-41 .

Zeidan, David. "Radical Islam in Egypt: A Comparison of Two Groups." In Revolutionaries and Reformers: Contemporary Islamist Movements in the Middle East, 11-22. Albany: State University of New York Press, 2003. 